\title{
Selective Production of Hydrogen via Steam Reforming of Glycerol by Magnesium- based Catalysts
}

\author{
Narasimha Reddy Ravuru ${ }^{\# 1}$, Sanjay Patel ${ }^{* 2}$, Nilesh Khalse ${ }^{\# 3}$ \\ ${ }^{1,2,3}$ Department of Chemical Engineering, Institute of Technology, Nirma University, Ahmedabad, Gujarat \\ ${ }^{1}$ narasimhareddy.ravuru@nirmauni.ac.in
}

\begin{abstract}
Production of $100 \mathrm{~kg}$ biodiesel generates $10 \mathrm{~kg}$ of glycerol as waste which is hazardous to environment. Considering environmental impact it's necessary to convert it into useful product. The steam reforming of glycerol was carried out to produce the hydrogen using magnesium with different supports. Various catalyst were prepared by wet impregnation method and performance was evaluated in a packed bed reactor over a wide range of operating conditions, and reaction parameters were optimized in order to maximize the hydrogen production with minimum carbon monoxide formation This study focuses on hydrogen production from glycerol via steam reforming in fixed bed catalytic reactor using magnesium catalyst over $\mathrm{Al}_{2} \mathrm{O}_{3}, \mathrm{TiO}_{2}, \mathrm{La}_{2} \mathrm{O}_{3}$ and $\mathrm{ZrO}_{2}$ supports for which feed ratio of glycerol to water was fixed which is $1: 9$ and flowrate $3 \mathrm{ml} / \mathrm{min}$ leading to temperature range of $600^{\circ} \mathrm{C}$ to $850^{\circ} \mathrm{C} .10 \% \mathrm{Mg}$ loaded on $\mathrm{Al}_{2} \mathrm{O}_{3}$ shows highest hydrogen yield and glycerol conversion. The various effects ofreaction temperature, $\mathrm{H}_{2} \mathrm{O} / \mathrm{glycerol}$ molar ratio, and the feed flow rate on the steam reforming of glycerol over were also examined. Various catalyst prepared by the wet-impregnation methodand characterized by $X$ ray diffraction technique, scanning electronmicroscopy (SEM) analysisand BET surface area analysis
\end{abstract}

Keywords: Biodiesel, Steam reforming, Glycerol, Hydrogen, Magnesium Catalyst,

\section{INTRODUCTION}

In $21^{\text {st }}$ century to overcome from addiction of fossil fuels is major issue. Biodiesel can be solution because it possess environmental favorable characteristic, which produced by transesterification of vegetable oil in which $10 \mathrm{wt} \%$ of glycerol produced as major by-product. Due to hike demand of a biodiesel, glycerol stock increases which leads to environmental issues. Reducing glycerol into useful chemical compounds is favorable [1]. Many researchers pays their attention to solve this problem. Conversion of glycerol into hydrogen is most interesting way of reduction of glut stock [2-3]. Various water reforming processes [4] used for conversion of glycerol to hydrogen. Amongst all steam reforming process is more benign over supercritical and liquid water reforming processes [5] which provides 7 hydrogen moles using single glycerol mole, however in practice 5.7 to 6 moles of hydrogen can be produced.Steam reforming of glycerol is largely endothermic and favors atmospheric pressure. The major reaction pictured as follows [6]:

$$
\mathrm{C}_{\mathrm{n}} \mathrm{H}_{2 \mathrm{n}+2} \mathrm{O}_{3}+\mathrm{nH}_{2} \mathrm{O} \rightleftharpoons \mathrm{nCO}_{2}+(2 \mathrm{n}+1) \mathrm{H}_{2}
$$

TABLE I. METHOD USED IN PRODUCTION OF HYDROGEN FROM GLYCEROL

\begin{tabular}{|l|l|c|}
\hline \multirow{2}{*}{ Sr. No. } & \multicolumn{2}{|c|}{ Descriptions of Method Used in Hydrogen Production from Glycerol } \\
\cline { 2 - 3 } & \multicolumn{1}{|c|}{ Method } & Energy Requirements \\
\hline 1 & Liquid phase reforming & High pressure, $\mathrm{T}<400^{\circ} \mathrm{C}[7]$ \\
\hline 2 & Steam Reforming & Atmospheric pressure, $\mathrm{T}>450^{\circ} \mathrm{C}[8-9]$ \\
\hline 3 & Partial oxidation gasification & Highly endothermic, $\mathrm{T}>900^{\circ} \mathrm{C}[10]$ \\
\hline 4 & Supercritical water reforming & $\mathrm{P}>$ Atmospheric pressure, $\mathrm{T}>384^{\circ} \mathrm{C}[11]$ \\
\hline 5 & Auto thermal reforming & $540^{\circ} \mathrm{C}<\mathrm{T}<1000^{\circ} \mathrm{C}[12]$ \\
\hline
\end{tabular}

Several study have been done using nickel catalyst in alcohol steam reforming with magnesium, cerium, and lanthanum as promoter [13]. By analyzing the action of impetus metals loaded on oxides $\left(\mathrm{CeO}_{2}, \mathrm{Y}_{2} \mathrm{O}_{3}, \mathrm{SiO}_{2}\right.$, $\mathrm{MgO}$ ), the lineup of catalyst $\mathrm{Ru}>\mathrm{Ni}>\mathrm{Co}>\mathrm{Pd}$ was best supported on $\mathrm{La}_{2} \mathrm{O}_{3}$. Amongst all $3 \mathrm{wt}$. $\% \mathrm{Rh} / \mathrm{Y}_{2} \mathrm{O}_{3}$ was found more efficient in conversion of glycerol and hydrogen conversion [14]. Co impetus loaded on economic supports such as $\mathrm{La}_{2} \mathrm{O}_{3}, \mathrm{YSZ}$ and 
$\mathrm{ZrO}_{2}$ were figured out for supercritical steam reforming. In which $10 \mathrm{wt} \%$ cobalt loaded on YSZ showed highest glycerol conversion [15]. Considering above study selection of catalyst and support shows important change in glycerol conversion and yield of hydrogen.

In this research synergistic study of magnesium catalyst loaded on $\mathrm{Al}_{2} \mathrm{O}_{3}, \mathrm{TiO}_{2}, \mathrm{La}_{2} \mathrm{O}_{3}$ and $\mathrm{ZrO}_{2}$ have been prepared and analyzed for production of hydrogen from glycerol via steam reforming.

\section{EXPERIMENTAL}

\section{A. Preparation of Catalyst}

Different batches of magnesium catalyst loaded on $\mathrm{Al}_{2} \mathrm{O}_{3}, \mathrm{TiO}_{2}, \mathrm{La}_{2} \mathrm{O}_{3}$ and $\mathrm{ZrO}_{2}$ was prepared.Magnesium nitrate hexahydrate $\left[\mathrm{Mg}\left(\mathrm{NO}_{3}\right)_{2} \cdot 6 \mathrm{H}_{2} \mathrm{O}\right]$ provided by $\mathrm{CDH}$ was used as metal precursor for magnesium. Formulation of catalysts were done by wet impregnation method. After loading of catalyst on support overnight drying provided on $110^{\circ} \mathrm{C}$ followed by calcination at $570^{\circ} \mathrm{C}$. Catalysts were sieved in $35-50$ mesh screen used in experiments.

\section{B. Catalyst Characterization}

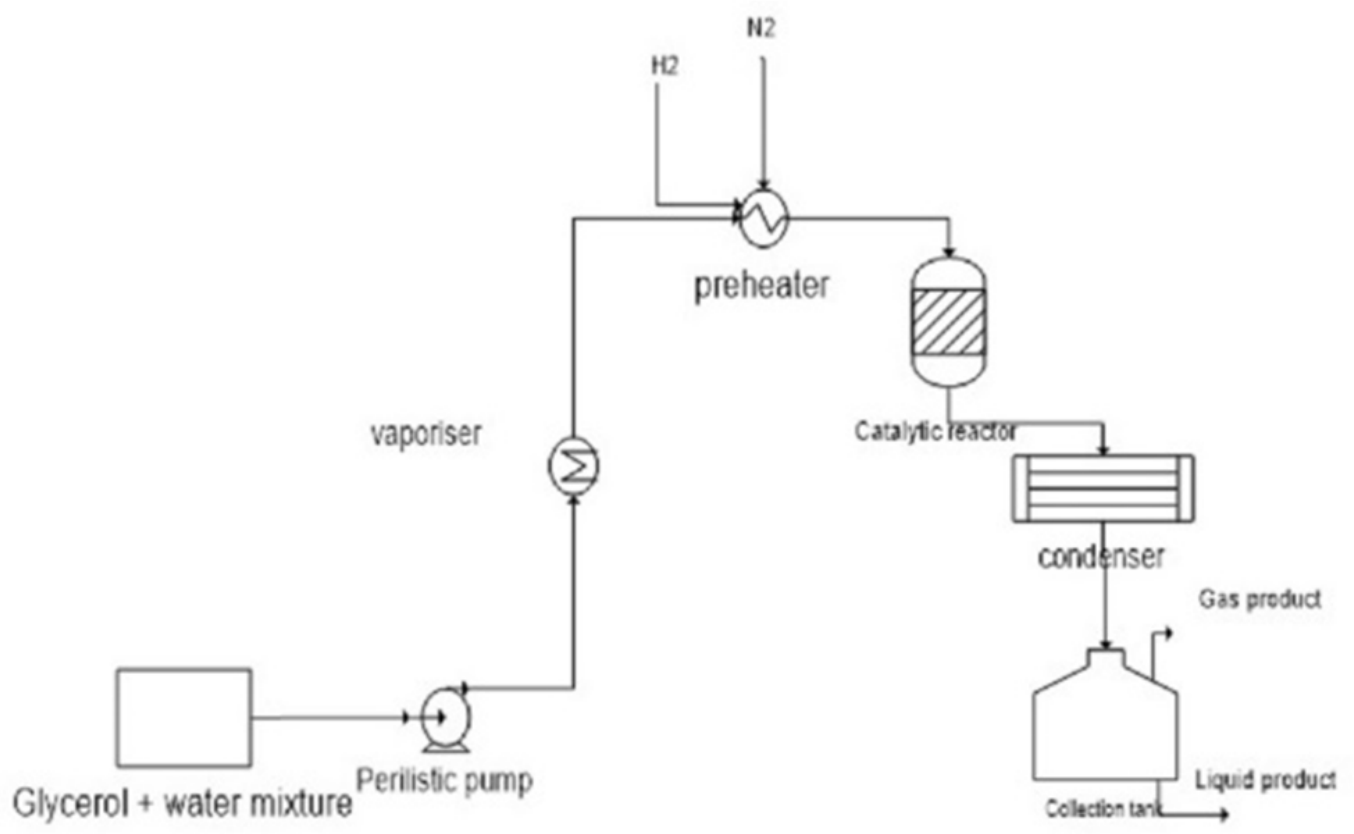

Fig. 1. Schematic of glycerol steam reforming setup [16]

The powder X-ray diffraction (XRD) by using a Philips X'pert MPD system instrument was carried out. For which diffraction angle $2 \Theta$ from $20^{\circ}$ to $80^{\circ}$ was kept employing Copper $\mathrm{K} \alpha$ radiation filtered by graphite, generator setting current of $30 \mathrm{~mA}$ and voltage of $40 \mathrm{kV}$. Continuous mode with very minute step interval applied. Thermo Gravimetry Analysis (TGA) for estimation of coke deposition done by using Mettler Toledo (Model No: TGA-180) instrument. $20 \mathrm{mg}$ of catalyst were weighed in alumina crucible with $10^{\circ} \mathrm{C} / \mathrm{min}$ of heating rate and $20 \mathrm{ml} / \mathrm{min}$ of nitrogen as carrier gas up to the $900^{\circ} \mathrm{C}$. The specific surface area of the impetuswas figured out using nitrogen adsorption-desorption isotherms measured at $-176^{\circ} \mathrm{C}$ in ASCP 2011 (Micromeritics) instrument. Samples were first evacuated for $5 \mathrm{~h}$ at $200{ }^{\circ} \mathrm{C}$ to remove moisture prior to adsorption-desorption experiments.The pore size distributions were calculated using the Barrett-JoynerHalenda $(\mathrm{BJH})$ formula. Pore volume and average diameter were also obtained from the pore size distribution curves using the software. The morphology of catalyst samples was obtained with magnification of 10000 , 25000,50000 by a scanning electron microscope (SEM) using a LEO 45 ic (JEOL) instrument operated at 10 $\mathrm{kV}$.

\section{Experimental preocedure}

The weighted amount of catalyst loaded in center of reactor supported by ceramic wool reduced by ramping the temperature of reactor by $10^{\circ} \mathrm{C}$ up to $450^{\circ} \mathrm{C}$ by flowrate $50 \mathrm{ml} / \mathrm{min}$ of hydrogen and $280 \mathrm{ml} / \mathrm{min}$ nitrogen as carrier gas. Glycerol and water in 1:9 mol ratio respectively fed by peristaltic pump at constant flowrate $3 \mathrm{ml} / \mathrm{min}$, followed by vaporizer at $250^{\circ} \mathrm{C}$, which again followed by pre-heater at $400^{\circ} \mathrm{C}$ causing conversion of liquid into fully vaporized form. Different temperature was set of a reactor for steam reforming ranging from $450^{\circ} \mathrm{C}$ to 
$850^{\circ} \mathrm{C}$. After completion of reaction product sent to condenser followed by gas liquid separator from which product sent to analysis. The actual experimental flow path shown in fig.1

\section{Product analysis}

The gaseous product separated at gas liquid separator was analyzed in Gas Chromatograph (Shimazdu GC-10) equipped with thermal conductivity detector (TCD) using Chincarbon CT100/120 micro packed column having dimension $3 \mathrm{~m}$ length and $1.2 \mathrm{~mm}$ inner diameter. For detection of $\mathrm{CO}_{2}, \mathrm{CO}, \mathrm{H}_{2}, \mathrm{CH}_{4}$ gas chromatograph calibrated before doing all the experiments by using pure samples of said gases. Activity of catalyst measured in terms of glycerol conversion, hydrogen yield and selectivity using following equations [17-20]:

$$
\begin{gathered}
\text { Glycerol conversion } \%=\frac{\left(\mathrm{CO}+\mathrm{CO}_{2}+\mathrm{CH}_{4}\right) \text { generated }}{\text { glycerol in feed } \times 3} \\
\% \mathrm{H}_{2} \text { yield }=\frac{\text { moles of } \mathrm{H}_{2} \text { generated }}{7 \times \text { moles of glycerol fed }} \times 100 \\
\% \mathrm{H}_{2} \text { selectivity }=\frac{\text { moles of } \mathrm{H}_{2} \text { generated }}{\mathrm{C} \text { atoms in gas product }} \times \frac{3}{7} \times 100 \\
\% \text { selectivity of } \mathrm{i}=\frac{i_{\text {out }}}{\left(\mathrm{CO}+\mathrm{CO}_{2}+\mathrm{CH}_{4}\right)_{\text {out }}} \times 100
\end{gathered}
$$

\section{RESULTS}

A. Effect of temperature on glycerol conversion:

As the temperature increases glycerol conversion also increases and highest seen in 10\% Magnesium loaded on aluminum oxide. Also the activity of catalyst for glycerol conversion in order of $10 \% \mathrm{Mg} / \mathrm{Al}_{2} \mathrm{O}_{3}>>$ $15 \% \mathrm{Mg} / \mathrm{Al}_{2} \mathrm{O}_{3}>15 \% \mathrm{Mg} / \mathrm{La}_{2} \mathrm{O}_{3}>10 \% \mathrm{Mg} / \mathrm{TiO}_{2}>15 \% \mathrm{Mg} / \mathrm{ZrO}_{2}$ was seen from all experiments according to temperature effect.

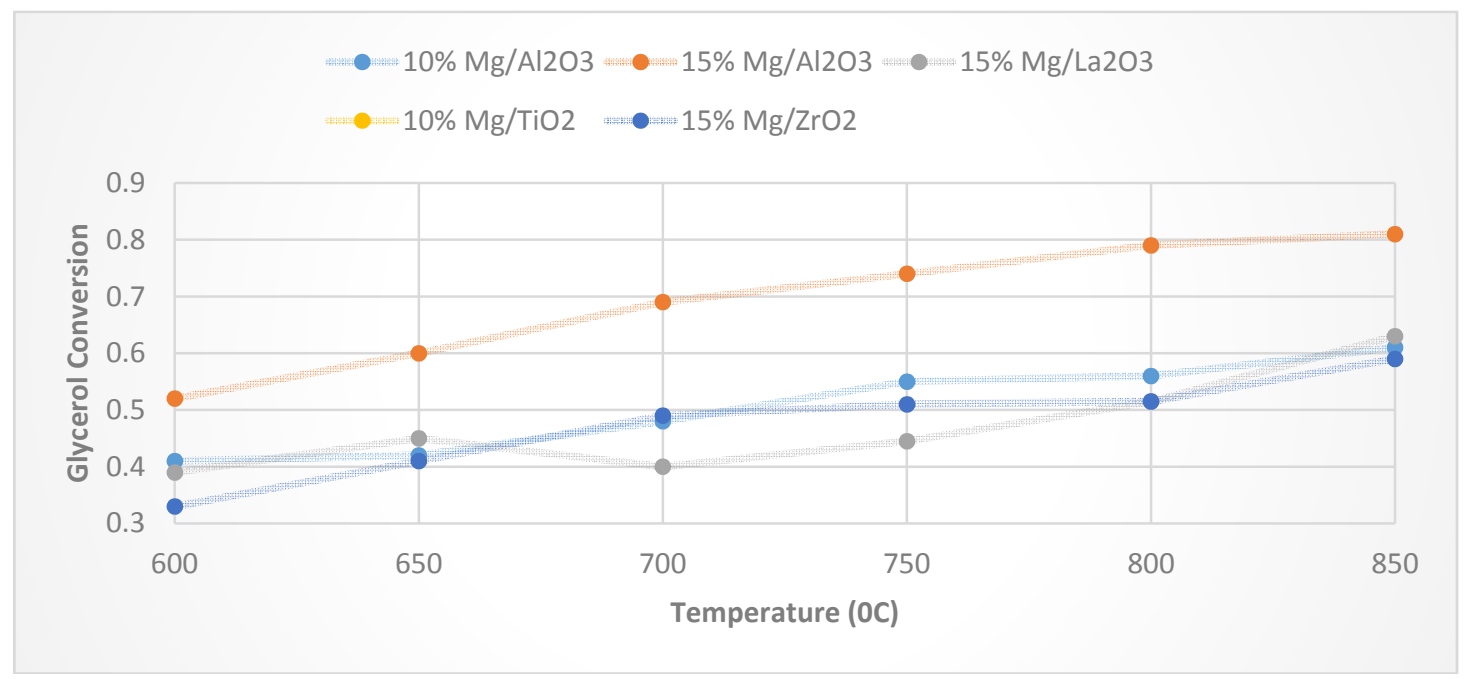

Fig. 2.Effect of temperature on glycerol conversion

B. Effect of temperature on hydrogen yield:

As the temperature increases hydrogen yield also increases and highest seen in 10\% Magnesium loaded on aluminum oxide. Also the activity of catalyst for hydrogen yield in order of $10 \% \mathrm{Mg} / \mathrm{Al}_{2} \mathrm{O}_{3}>>15 \% \mathrm{Mg} / \mathrm{Al}_{2} \mathrm{O}_{3}>$ $15 \% \mathrm{Mg} / \mathrm{La}_{2} \mathrm{O}_{3}>10 \% \mathrm{Mg} / \mathrm{TiO}_{2}>15 \% \mathrm{Mg} / \mathrm{ZrO}_{2}$ was seen from all experiments according to temperature effect. 


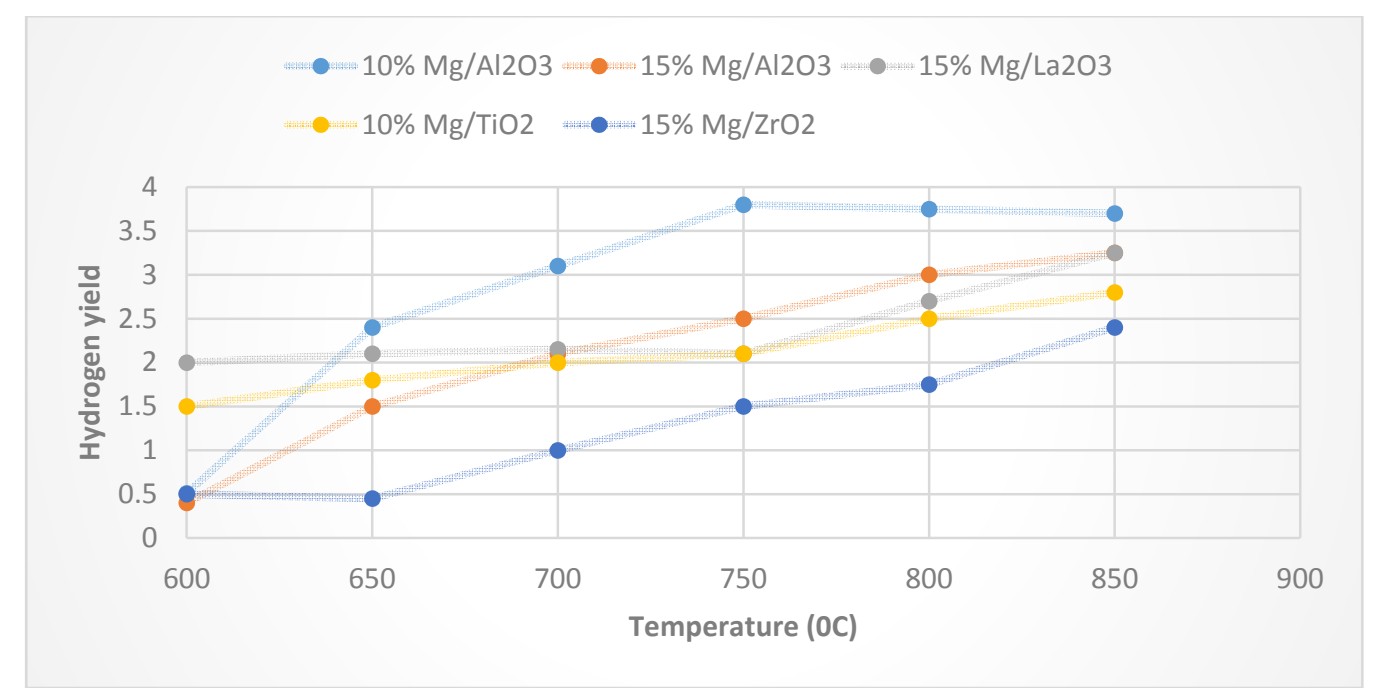

Fig. 3. Effect of temperature on hydrogen yield

\section{Characterization result:}

For all the runs of experiments it was seen that glycerol conversion and hydrogen yield is highest in $10 \% \mathrm{Mg} / \mathrm{Al}_{2} \mathrm{O}_{3}$. So for same catalyst X-ray diffraction(XRD) by JCPDS card no. 98-062-1716 and thermogravitometric along with BET and SEM investigation was done. From XRD it was concluded that pure phases of magnesium and aluminum oxide formed in catalyst and from TGA we can say that after heating catalyst at $900^{\circ} \mathrm{C}$ it can be reused. Figure 4,5 shows the XRD and TGA analysis respectively.

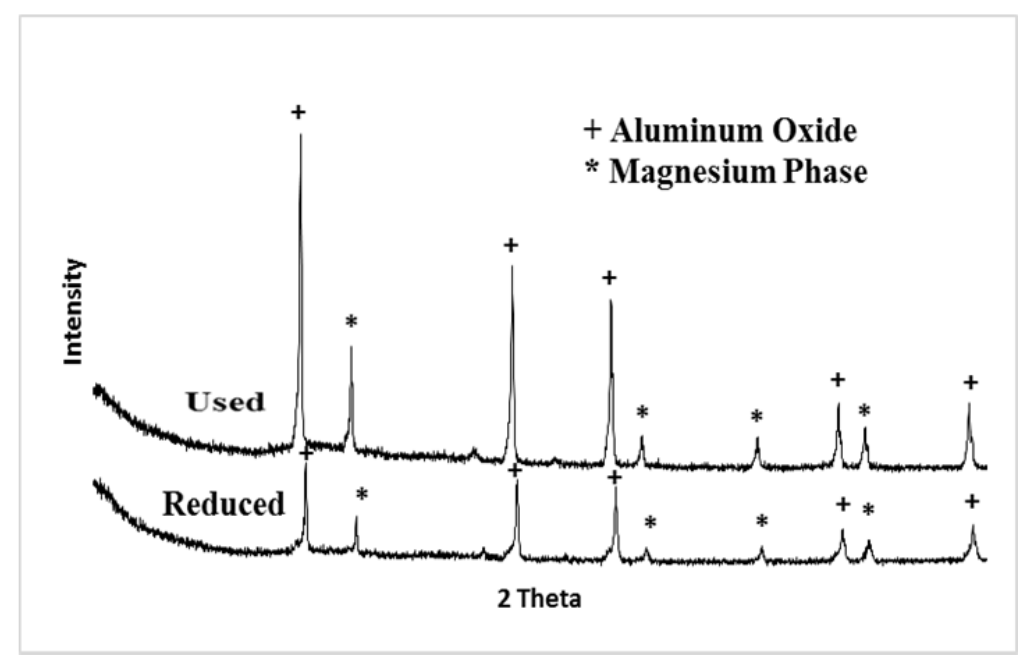

Fig. 4. XRD graph for $10 \% \mathrm{Mg}$ loaded on aluminum oxide 
ISSN (Print) : 2319-8613

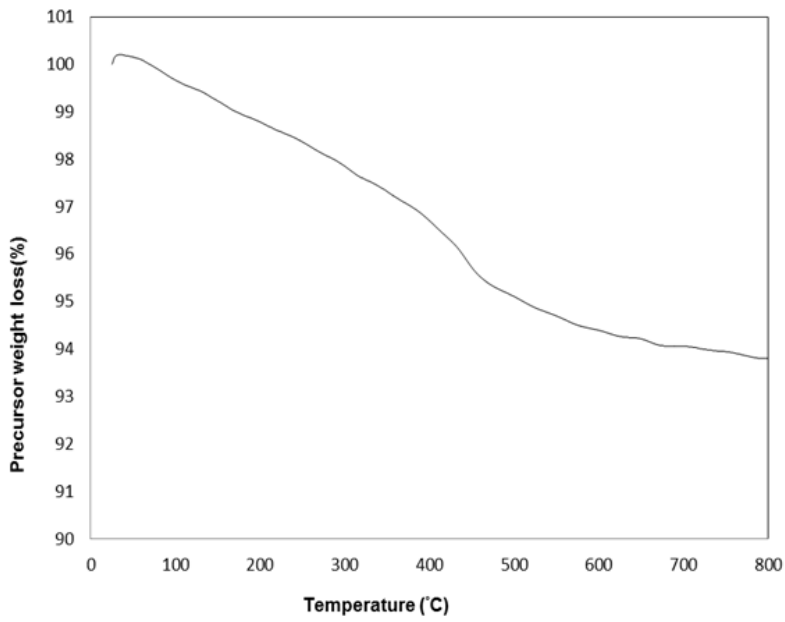

Fig. 5. TGA graph for $10 \% \mathrm{Mg}$ loaded on aluminum oxide 1

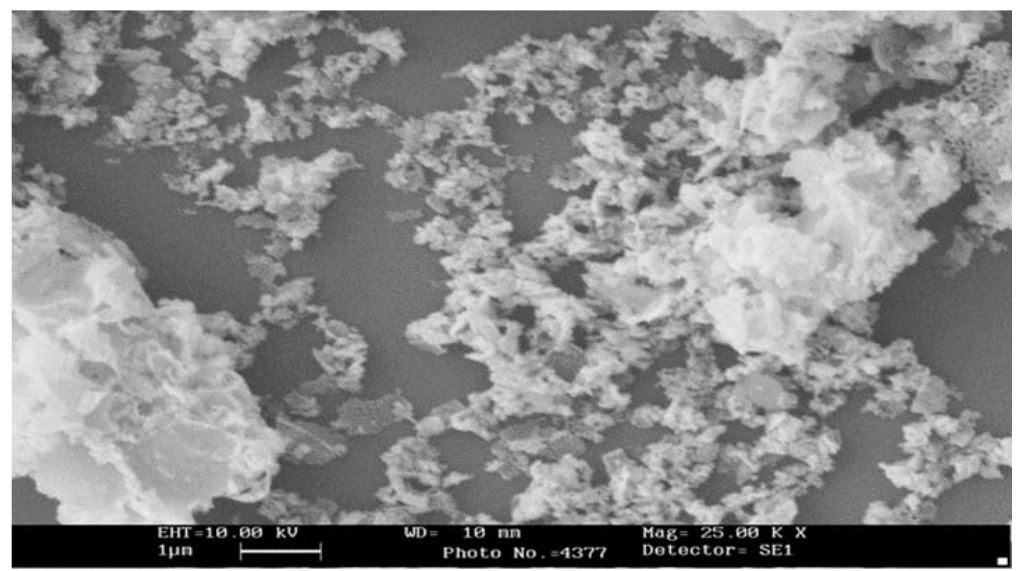

Fig. 6. SEM image for calcined $10 \% \mathrm{Mg}$ loaded on aluminum oxide catalyst

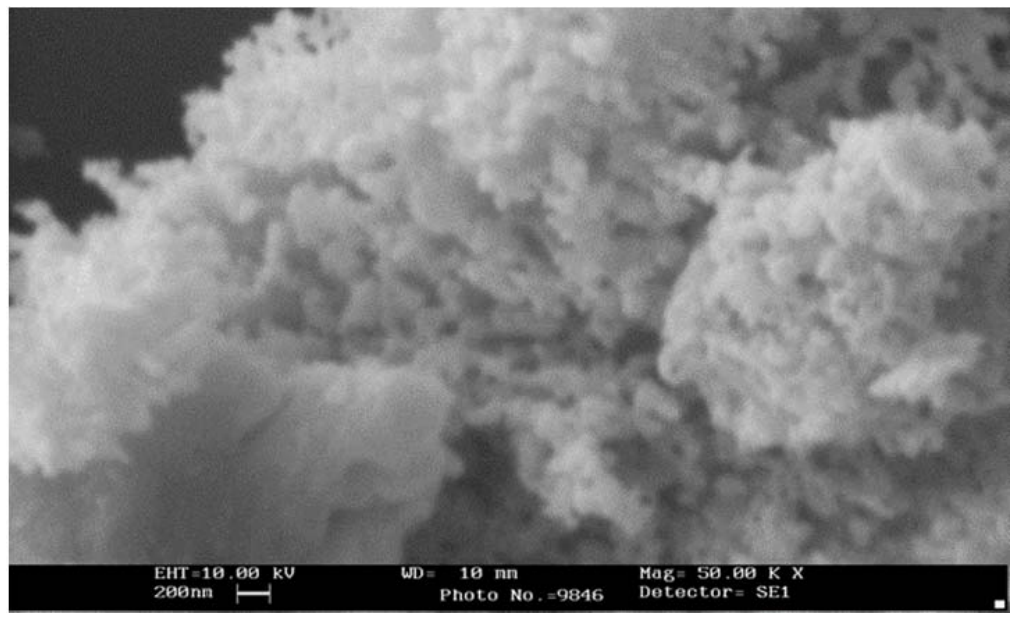

Fig. 7. SEM image for used $10 \% \mathrm{Mg}$ loaded on aluminum oxide catalyst 
TABLE II. BET ANALYSIS

\begin{tabular}{|c|c|c|c|c|c|}
\hline Catalyst & $\begin{array}{c}\text { Calcination } \\
\text { temperature } \\
\text { and duration }\end{array}$ & $\begin{array}{c}\text { Crystallite } \\
\text { size dXRD } \\
(\mathbf{n m})\end{array}$ & $\mathbf{B E T}\left(\mathbf{m}^{2} / \mathbf{g}\right)$ & $\begin{array}{c}\text { Pore } \\
\text { size } \\
(\mathbf{n m})\end{array}$ & $\begin{array}{c}\text { Pore } \\
\text { volume } \\
\left(\mathbf{c m}^{3} / \mathbf{g}\right)\end{array}$ \\
\hline $10 \% \mathrm{Mg} / \mathrm{Al}_{2} \mathrm{O}_{3}$ & $600^{\circ} \mathrm{C}, 5 \mathrm{~h}$ & 33.68 & 13.44 & 10.53 & 0.0354 \\
\hline $15 \% \mathrm{Mg} / \mathrm{Al}_{2} \mathrm{O}_{3}$ & $600^{\circ} \mathrm{C}, 5 \mathrm{~h}$ & 42.09 & 8.78 & 9.77 & 0.0215 \\
\hline $15 \% \mathrm{Mg} / \mathrm{La}_{2} \mathrm{O}_{3}$ & $900^{\circ} \mathrm{C}, 5 \mathrm{~h}$ & 42.13 & 5.5 & 6.75 & 0.0092 \\
\hline $10 \% \mathrm{Mg} / \mathrm{TiO}_{2}$ & $750^{\circ} \mathrm{C}, 5 \mathrm{~h}$ & 42.09 & 3.04 & 11.29 & 0.0086 \\
\hline $15 \% \mathrm{Mg} / \mathrm{ZrO}_{2}$ & $550^{\circ} \mathrm{C}, 5 \mathrm{~h}$ & 31.24 & 3.91 & 8.32 & 0.0081 \\
\hline
\end{tabular}

The morphology of the catalyst samples was investigated by scanning electron microscopy (SEM). SEM result shows that wet impregnation method was capable of producing more uniform particle having the size close to $150 \mathrm{~nm}$ in case of catalyst $10 \% \mathrm{Mg}$ loaded on aluminum oxide. The SEM micrograph of $10 \% \mathrm{Mg}$ loaded on aluminum oxide used catalyst sample is presneted in Fig. 5,6 shows that the particles had a porous and uniform struture. Table II show BET anlaysis data.

\section{Conclusion:}

Steam reforming of glycerol yielding in hydrogen is one of the most attractive way of hydrogen production. Hydrogen produced from steam reforming yields 4 to 5 moles comparing to 7 moles as stoichiometric conversion. Also from all the support used aluminum oxide with magnesium was best combination which provide 4 moles of hydrogen at $850^{\circ} \mathrm{C}$ with $3 \mathrm{ml} / \mathrm{min}$ of feed in proportion of $1: 9$ of glycerol to hydrogen. Glycerol can be converted in clean energy hydrogen by steam reforming effectively.

\section{References:}

[1] Thompson JC, He BB. Characterization of crude glycerol from biodiesel production from multiple feedstocks. ApplEngAgric 2006; 22(2):261-5.

[2] Retrieved from World Wide Web http://biodiesel.org/resources/faqs/ on Feb 17, 2016.

[3] Pachauri N, He B. 2006. Value-added utilization of crude glycerol from biodiesel production: a survey of current research. American Society of Agricultural and Biological Engineers Annual Meeting, Portland

[4] Dunn S. Hydrogen futures: toward a sustainable energy system. Int J Hydrogen Energy 2002; 27:235-64

[5] Ewan BCR, Allen RWK. A figure of merit assessment of the routes to hydrogen. Int J Hydrogen Energy2005; 30(8):809-19.

[6] Soares RR, Simonetti DA, Dumesic JA. Glycerol as a source for fuels and chemicals by low-temperature catalytic processing. AngewChemInt Ed 2006; 45:3982-5.

[7] Wu T, Yan Q, Wan H. Partial oxidation of methane to hydrogen and carbon monoxide over a $\mathrm{Ni} / \mathrm{TiO}_{2}$ catalyst. J MolCatal A: Chem $2005 ; 226: 41-8$.

[8] Cortright RD, Davda RR, Dumesic JA. Hydrogen from catalytic reforming of biomass-derived hydrocarbons in liquid water. Nature 2002, 964-976.

[9] Czernik S, French R, Feik C, Chornet E. Hydrogen by catalytic steam reforming of liquid byproducts frombiomass thermoconversion process. IndEngChem Res 2002; 41:4209-15.

[10] Swami SM, Abraham MA. Integrated catalytic process for conversion of biomass to hydrogen. Energy Fuels 2006, 2616-22.

[11] Dauenhauer PJ, Salge JR, Schmidt LD. Renewable hydrogen by auto thermal steam reforming J.Catal,2006;238-47.

[12] Adhikari S, Fernando S, Haryanto A. Glycerin steam reforming for hydrogen production. Trans, ASABE,2007;50(2):591-5.

[13] Adhikari S, Fernando S, Haryanto A, Production of hydrogen by steam reforming of glycerin over alumina supported metal catalysts. Catal Today, 2007, article in press.

[14] Freni S, Cavallaro S, Mondello N, Spadaro L, Frusteri F. Production of hydrogen for MC fuel cell by. steam reforming of ethanol over $\mathrm{MgO}$ supported $\mathrm{Ni}$ and Co catalysts. CatalCommun 2003;4(6): 259-68.

[15] Wanat EC, Venkataraman K, Schmidt LD. Steam reforming and water-gas shift of ethanol on Rh and Rh-Ce catalysts in a catalytic wall reactor. ApplCatal A: General 2004;276(1-2): 155-62.

[16] Hirai T, Ikenaga NO, Mayake T, Suzuki T. Production of hydrogen by steam reforming of glycerin on ruthenium catalyst.EnergyFuels2005; 19:1761-2.

[17] Iriondo A. Hydrogen production from residual glycerol obtained from biomass transesterification, San Francisco, CA: American Chemical Society Meeting; 2006.

[18] Frusteri F, Freni S, Chiodo V, Donato S, Bonura G, Cavallaro S. Steam and auto-thermal reforming of bio-ethanol over $\mathrm{MgO}$ andCeO Ni supported catalysts. Int J Hydrogen Energy 2006; 31(5):2193-9.

[19] Adhikari S, Fernando S, Haryanto A comparative thermodynamic and experimental analysis on hydrogen production by steam reforming of glycerin. Energy Fuels 2007; 21(4):2306-10.

[20] Sanjay Patel, K.K. Pant, Selective production of hydrogen via oxidative steam reforming of methanol using $\mathrm{Cu} \mathrm{Zn}-\mathrm{Ce}-\mathrm{Al}$ oxide catalysts, Chemical Engineering Science 2007; 62: 5436 - 5443.

\section{AUTHOR PROFILE}

Narasimha Reddy Ravuruis working as an Assistant Professor in Chemical Engineering Department of Institute of Technology in Nirma University, Ahmedabad. He has obtained his B.Tech. in Chemical Engineering from Madras University in the year 2000 and Masters in Chemical Engineering from The IIT, Madras in year 
2006. His research interest includes Catalysis. He is a Life member of ISTE. He is having teaching experience of 16 years.

Sanjay Patel is working as a Professor in Chemical Engineering Department of Institute of Technology in Nirma University, Ahmedabad. He has obtained his B.E. in Chemical Engineering from DDIT, Nadiad in the year 1997 and Masters in Chemical Engineering from The IIT, Delhi in year 2004. He has completed his Ph.D. from IIT, Delhi in year 2007. His research interest includes Catalysis. He is a Life member of ISTE. He is having teaching experience of 20 years. 